\title{
The nesting and mating behavior of Andrena patella (Hymenoptera: Andrenidae)
}

\author{
Showket A. Dar ${ }^{1}$, Munazah Yaqoob ${ }^{1}$, and Ivana Tlak Gajger ${ }^{2 *}$ \\ ${ }^{1}$ Division of Agricultural Entomology, Sher-e-Kashmir University of Agricultural Sciences and Technology, \\ Kashmir, India \\ ${ }^{2}$ Department for Biology and Pathology of Fish and Bees, Faculty of Veterinary Medicine, University of Zagreb, \\ Zagreb, Croatia
}

DAR, S. A., M. YAQOOB, I. TLAK GAJGER: The nesting and mating behavior of Andrena patella (Hymenoptera: Andrenidae). Vet. arhiv 91, 207-219, 2021.

\section{ABSTRACT}

This study of nesting and associated behavior patterns of Andrena patella was carried out at 27 locations with different landscape categories, from 2013 to 2016. The research areas chosen were generally flat or marshy areas. A total of 15 major nest aggregations were spotted and 120 nests were excavated. This species nests in soil, males emerge earlier than females, and mating occurred on flowers during the foraging season, in the $3^{\text {rd }}$ week of May. The various nest and cell parameters showed low variability in the different years and different sites, but nest cell length, diameter and number varied significantly, as well as depth even at the same site. The nests were multi-cellular, oblique to horizontal, and cell shape was oval. The mating attempts of the pairs and copulatory behavior involved various steps which were completed in a very few seconds. The males appeared first on the flowers, near to the nesting site, and lived shorter than the females. The females started foraging in the $2^{\text {nd }}$ to $3^{\text {rd }}$ weeks of May and laid eggs in the $1^{\text {st }}$ week of June. The adult phenology, egg placement, cell provision and larval feeding are described.

Key words: Andrena patella phenology; behavior; development stages; pollen and nectar provision

\section{Introduction}

Nest-building is an elementary behavior of organisms which have the innate tendency to build a nest (DEMERE et al., 2002). Insect nesting behavior includes the nest arrangement, nesting biology and brood development (BOHART and YOUSSEF, 1976; ROZEN et al., 2009; BARBOSA et al., 2013). The published studies focus on the different aspects of behavior: provisioning behavior and flight, reproduction rates (DANFORTH, 1991; BISCHOFF et al., 2003), time and energy costs,

sex ratios and food availability (GIOVANETTI and LASSO, 2005), as well as population genetics (KATERINA, 2013). However, detailed studies describing the different nest behavioral patterns of rear Andrenidae bees, at and inside the nesting burrow are quite rare. Nesting aggregation is a very interesting step from the insect's solitary life and its social life strategy. Each female lays eggs in a separate nest in suitable habitats and behaves in a

*Corresponding author:

Prof. Ivana Tlak Gajger, PhD, DVM, Department for Biology and Pathology of Fish and Bees, Faculty of Veterinary Medicine, University of Zagreb, Heinzelova 55, 10000 Zagreb, Croatia, Phone: +385 12390 151; Fax: +385 12390 211; E-mail: ivana.tlak@vef.hr 
solitary manner (ALCOCK, 1975; TLAK GAJGER et al. 2014; TLAK GAJGER et al., 2015; DAR et al., 2017). In addition to the flat soil surfaces and marshy areas, the majority of bee species build their nests in several substrates, such as subterranean cavities, tree trunks, branches, rock crevices, brick walls, termite nests or active nests attached to branches (ROUBIK, 2006). The Anthophora pueblo were found to dig nests in hard sandstone rather than soft soil (ORR et al., 2016). The nest wall of Bombus pascuorum is made up of an intricate organic matrix, lined with calcific casts (PARKER et al., 2016) or with an organic lining for fossil bees (ROCHE et al., 2014). The nest architecture of $A$. patella consists of a single, main vertical shaft and several oblique to horizontal laterals, each terminating in a single vertical cell (DAR et al., 2017). The morphology of the cell is distinctive, as it has a discrete wall separated from the substrate (ROZEN, 1993), with varied nest depths even at the same location (MILICZKY, 2016). In the species Oxaea austere, the nest is hard, in red lateritic soils with dense grass cover, with a long vertical shaft, and a radiating, horizontal tunnel connected to the vertical burrow (SARZETTI et al., 2014). Further, each nest is occupied by two active females, also containing older cells, with a spiral closure and an antechamber. After locating a suitable hole, the mated female begins to build little "cells" which are usually placed linearly along a tunnel, and stocks the oval shaped cells with a mix of pollen and nectar and lays an egg, closes each cell and starts on the next one, capping the first one. During their life time, most bees will go on to build more nests. A nest of Megachile rotundata is composed of a string of individual units, which are concave at the bottom (KEMP and BOSCH 2000; MILIUS, 2007). The females collect nectar and pollen, regurgitate the nectar provisions for their brood and then transfer the pollen that is attached to their scopa (MOUNTCASTLE et al., 2015). Each nest cell contains one pollen ball and one egg (PARKER et al., 2016). A. patella, A. barbilirbis and $A$. cineraria bees have been observed to reside in marshy fallow land near fruit orchards and build deep nests, with the cavity guarded by a tumulus (DAR, 2017). Further, during the active flight season, the males of the A. agilissima attempt to find mates by positioning themselves at the sites where females are likely to be, specifically at the nesting site (GESLIN et al., 2016; PAXTON et al., 1999). A. patella females, similar to stingless bees, are receptive to mating soon after leaving the nest when mature, and after mating once in spring, they permanently leave the nest (PAXTON et al., 1999). The male A. patella search for unmated females in the early blooming period on stone fruit flowers.

The aim of this study was to expand knowledge about $A$. patella mating and nesting behavior patterns. This knowledge can contribute significantly to development of a strategy for efficient plant pollination and wild bee conservation.

\section{Materials and methods}

Studied organism. Andrena is the largest genus within the Andrenidae family, with about 1400 registered species, but the real number might be around 2000 (MAYR and ASHLOCK, 1991). This genus, commonly called a mining bee, is spread all over the world, except in Oceania and South America (BAKER, 1995). Specimens are often brown to black, with mostly whitish, or rarely reddish, metallic blue or green abdominal hair bands. The females possess a broad velvety area called facial foveae between the compound eyes and the antennal bases, long scopal hairs on the trochanters of the hind legs, and a black triangle called the pygidial plate at the abdominal apex. The average body length of females is $13.75 \mathrm{~mm}$. Males are smaller than the females, with an average body length of $11.01 \mathrm{~mm}$ (KUMAR and DEY, 2018). The genus Andrena is polylectic. Mining bees are short tongued and have an important role in plant pollination in areas where honeybees fail to pollinate because of extremely low temperatures. Both males and females emerge from the underground cells where they overwinter as pre-pupae. After mating, the adult females build the nest cells, which contain pollen mixed with nectar, upon which an egg is laid before each cell is sealed (KUMAR and DEY, 2018).

Habitat. A. patella needs a flat soil surface to nest on and it typically feeds on flowers from various fruit orchards. This bee forages close to the area that 
can be used as a nesting site. Changing agricultural landscapes have reduced their natural habitats, so the species is limited to barren land, footpaths, and the edges of fields (DAR et al., 2018).

Study area. Nesting aggregations were investigated in 27 experimental locations, with altitudes ranging from 1613 to $2730 \mathrm{~m}$ above sea level. The area is covered with snow clad mountains in winters, and allows the growth of wild flowers during the spring and summer. The bee populations were studied from May to end July, for four consecutive years, in experimental locations of the Kashmir valley (Srinagar, Pulwama and Budgam), in India. In Budgam, the nest aggregations covered an area of $5.75 \mathrm{~km}^{2}$; while in Srinagar and Pulwama the areas covered 2.90 and $3.74 \mathrm{~km}^{2}$, respectively. The survey was conducted in different valley landscapes and more preferably where the bee populations were situated on level ground along roads near apple and stone fruit orchards.

Observations and measurements. The nesting activities were observed from May to July (2013 to 2016) four days per week and three times per day commencing from morning (11:25 am, 2:10 $\mathrm{pm}$ and 4:45 pm) to evening. Individual observation intervals lasted 30 minutes and the total time duration taken for recording the nesting activities was 360 minutes/week. The density of the nests in each location was determinated by measuring of a 20 by $20 \mathrm{~cm}^{2}$ of soil surface by measuring tape. Procedure was repeated minimum of 10 times per nesting aggregation. The nest density was measured from the $1^{\text {st }}$ to the $2^{\text {nd }}$ week of May 2013, 2014, 2015 and 2016; and again, at the end of July each year. The nests were excavated using a sharp knife in mid-May and again at the end of July, observed for nest burrows, cells and depth. The light dust from the depth of the burrow and narrow cells were gently removed using an air pump. All bee specimens per nest were counted and collected in glass jars. The females' activity at the nesting sites was monitored from $24^{\text {th }}$ May to $5^{\text {th }}$ June. Additional observations at these sites were made in the $2^{\text {nd }}$ week of June (2014, 2015).

The observations of the adult bees' activity were measured by digital watch, in seconds. The temperature was measured in the shade using a mercury thermometer. In addition, notes on cloudiness and estimates of wind speed were made periodically, especially when changing conditions appeared to affect bee activity. The blocks of soil excavated containing burrows and cells were removed, and the dimensions of the cells and provision masses were determined to the nearest 0.1 $\mathrm{mm}$ with a Vernier caliper. The cells containing eggs were counted, and pollen balls were weighed. The weights of the provision masses were determined on a $0.001 \mathrm{~g}$ digital scale using a Sartorius electronic balance. The nest wall, and the internal and external surfaces were observed by magnifying glasses. A measuring tape was used to record the depth of the nest, after the complete burrow had been excavated. At the end of June, the excavated nests contained eggs on pollen balls, situated in the oval cells. The larvae of $A$. patella were kept at room temperature in their nest cells. Cells were placed on a layer of soil in a tightly closed plastic container and the soil was moistened periodically to maintain higher relative humidity.

Mating behavior. The foraging plants for the Andrena species during the early spring are stone fruit crops (Prunus avium and Prunus domestica), which bloom from mid-April in temperate areas of Kashmir. Generally, the adult females emerge at the end of the $2^{\text {nd }}$ week of May $\left(9^{\text {th }}-12^{\text {th }}\right)$, males in the $1^{\text {st }}$ week of May $\left(5^{\text {th }}\right)$, nearly four to seven days earlier than females, and due to the floral cues, the females are attracted to the stone fruit flowers. The females remain continuously in the searching mood, moving from one twig to another in sunny, warm weather. From the $3^{\text {rd }}$ week $\left(17^{\text {th }}\right)$ of May to the $1^{\text {st }}$ week of June, 9 attempts $\left(2^{\text {nd }}, 4^{\text {th }}, 9^{\text {th }}, 12^{\text {nd }}, 14^{\text {th }}, 16^{\text {th }}, 17^{\text {th }}, 20^{\text {th }}\right.$ May and $3^{\text {rd }}$ June) at mating were recorded under field conditions, near to the nesting sites, about 25 $\mathrm{m}$ away from fruit orchards, at a mean temperature of $21{ }^{\circ} \mathrm{C}$, relative humidity (RH) $75 \%$ and no wind. The bees were spotted on upper floral twigs, at 3.4 meter from the ground, and were observed for a total of 25 minutes with a high-resolution clear quality and adjustable 20x50 binocular telescope (JM Bushnell Waterproof 20x Zoom, 20x50 prism). The observations were recorded from the approach of the male until mating ended. The male moves towards the female and touches her with his antennae. The 
female stops moving and foraging, indicating her willingness to mate. Various phases involved in mating efforts consist of many successful struggles, such as: a) the pre-mounting phase, b) the mounting phase, c) the post-mounting phase, d) the copulatory phase and e) the post-copulatory phase all measured with respect to the time period during which the particular event took place. The copulatory phase involved various responses and struggles by many pairs. The stopwatch timer (Extech Instrument 365515 , Tanotis) with an accuracy of 0.01 second was kept on when an event occurred, and off when the event ended.

Statistical analysis. The rough data from the experimental locations were analyzed using SPSS 13.0 software (SPSS Inc., München, Germany) and R-software. We use the $\chi^{2}$ test, Tukey's Multiple Comparison Test and Poisson's Distribution. For variations of depth, principle component analyses (PCA) were performed, and the main variable factors were observed which comprised the major influence on the nest cell characteristics overall. As we changed the rate parameter (soil depth) $\lambda$, we changed the probability of seeing different numbers of cells in one interval:

$$
P(k \text { events in interval })=e^{-\lambda} \frac{\lambda^{k}}{k !}
$$

The actions of mating behavior were recorded, and the significance of various behavioral elements was estimated using the non-parametric KruskalWallis test, and Student's $t$-test and logistic regression were used to test the success of various behavioral elements. The probability of all courtship sequences (moving from one behavioral step to another) were estimated by using the Markovian behavioral transition matrix for total frequency of transitions.

\section{Results}

Fifteen nest aggregations were discovered during the blooming period of apple and stone fruit crops from 2013 to 2016 . The center of the path was hard and compact without any grass, except the Cynodon dactylon runners around the nest burrow on flat ground. The sites were protected from the wind, and provided with a favorable microclimate.
The nests of some other species e.g. Lasioglossum marginatum were also found in and around the sites in the same direction. The nests were observed on flat, leveled ground with scattered grassy patches in the $2^{\text {nd }}$ week of May ( $11^{\text {th }}$ May). Bee activity began to increase in the morning until the evening and later decreased, when the air temperature decreased at sunset. 36 surveys were performed to monitor nesting activity and in the $3^{\text {rd }}\left(16^{\text {th }}, 17^{\text {th }}, 19^{\text {th }}\right.$ May $)$ to the $4^{\text {th }}$ week of May $\left(21^{\text {st }}, 26^{\text {th }}, 27^{\text {th }}\right.$ May), the female activity around the nest burrow was at its maximum, compared to the beginning of May $\left(1^{\text {st }}\right.$ and $2^{\text {nd }}$ weeks) and the $1^{\text {st }}$ week of June. In the $1^{\text {st }}$ $\left(6^{\text {th }}, 7^{\text {th }}\right)$ to $2^{\text {nd }}\left(12^{\text {th }}, 15^{\text {th }}\right)$ weeks of June, the bees stopped foraging and started laying eggs.

Behavior observations. Male individuals of $A$. patella were observed flying on $7^{\text {th }}$ and $9^{\text {th }}$ May $\left(1^{\text {st }}\right.$ week) near the nest cavity. Due to the increase in air temperature, the average soil temperature (10 $\mathrm{cm}$ below the surface) also increased from 2.75 and $3.26{ }^{\circ} \mathrm{C}$ on $5^{\text {th }}$ to $8^{\text {th }}$ May to 4.43 and $5.66{ }^{\circ} \mathrm{C}$ on $9^{\text {th }}$ to $11^{\text {th }}$ May, respectively. Almost eight males were found flying in a zig-zag fashion on $7^{\text {th }}$ (one captured), $8^{\text {th }}$ ( 3 captured) and $10^{\text {th }}$ (4 captured) of May, approximately 10 meters from the nesting sites, flying at $1.5 \mathrm{~m}$ to $2.33 \mathrm{~m}$ above the ground. During this flight pattern, the average air temperature values were 14.25 to $20.43{ }^{\circ} \mathrm{C}$. From the $2^{\text {nd }}$ week $\left(13^{\text {th }}\right.$ onwards) of May, the activity of the bees was enhanced resulting in higher foraging activity. The males made short flights near the grass, bushes, the stems of fruit trees, along the branches, near flowers, apparently searching for females near the nesting locations. The results showed that during the active flight period of one month on sunny days, the males made flights at midday, above the ground near the nesting site, up to 5 to 12 meters away from the main entrance to the nest. The males were observed patrolling blooming cherry, apricot and apple trees, and various weeds and shrubs growing in various landscapes at variable elevations and degrees of slope. The earliest observations of males patrolling were recorded in the $2^{\text {nd }}$ week of May $\left(9^{\text {th }}\right.$ and $10^{\text {th }}$ May) on cherry flowers. On average the males' activities last until the $3^{\text {rd }}$ week $\left(20^{\text {th }}\right)$ of May to the $2^{\text {nd }}$ week of June, and they disappeared earlier than the females. 
The foraging activities of female A. patella on cherry trees were first recorded on $15^{\text {th }}, 17^{\text {th }}$ and $18^{\text {th }}$ of May (2013) between 10:30 to 2:20 hours, at a mean temperature of $19^{\circ} \mathrm{C}, \mathrm{RH} 75 \%$, and calm wind. The females showed activity from 9:50 to 16:30 hours. The orientation flights described a roughly round to figure-of-eight pattern around the nest. Sometimes the bees were oriented at 3 to $4 \mathrm{~m}$ distance from the nest. The nest entrance remained open while the bees foraged. However, a soil plug was observed in a nest entrance on the three occasions, twice late in the day on $16^{\text {st }}$ May after foraging had ceased, and once on $25^{\text {th }}$ May when foraging had begun. The females had greater longevity than the males and disappeared in the $3^{\text {rd }}$ week of June.

Immature stages and provision mass. During nest excavation, provision masses were observed in abundance at the lowest depth (30.48 to $45.72 \mathrm{~cm}$ ) from main nest entrance. A total of ten complete provision masses were obtained from the nesting sites at the experimental locations. Almost all the examined masses were similar and consisted of firm and compactly packed pollen that had been moistened to a soft, flabby and doughy consistency, presumably by nectar. The study showed that nearly 7 provision masses were sub-circular with maximum diameter of $4.09 \mathrm{~mm}$ and had been placed the in lower end of the cells. On average, the masses were shaped into flattened spheres, 2.39 to $2.43 \mathrm{~mm}$ thick and had a regular surface, free from perceptible projections, lumps and indentations. One mass was incomplete, $2.98 \mathrm{~mm}$ diameter, imperfectly spherical, with a smooth worked surface without lumps. Overall, 5 masses were complete, weighing $0.1321 \mathrm{~g}, 0.1354 \mathrm{~g}, 0.1476$ and $0.1698 \mathrm{~g}$, while since one mass was incomplete it weighed only $0.0023 \mathrm{~g}$.

The eggs were markedly curved, slightly bent, creamy, smooth and oily, touching the provision mass on anterior and posterior sides. The posterior end of the egg was towards the lateral side of the provision ball, fixed in its worked surface; while the anterior end was towards the front axis of the cell, just making light contact. The axis of both the cell and the egg were parallel to each other. Among the total 16 eggs observed, one was $2.45 \mathrm{~mm}$ long and slightly less than $1.0 \mathrm{~mm}$ in diameter. However, larval feeding was not observed perfectly, but new substantially enclosed larvae lay on top of the middle part of the provision mass, with a long axis parallel to the cell axis. Feeding by the larva begins just beneath their head, which is towards the cell closure. Slowly, the orientation of the larva changed, generally when a considerable amount of provision mass had been consumed. The feeding continued, allowing the larva to reach progressively farther forward and downward at the front of the mass, while side to side movement of the head allowed it to reach farther laterally. In the lateral stages of feeding, the larva wrapped tightly around the remains of the provisions.

Nest structure. The females spent the early days of the active season in the deep vertical burrow without cells. They deepened the nest burrows later, and subsequently distinct parts were formed, located slightly obliquely to the horizontal line. At a certain depth, the female built the first cell at the end of the burrow. The cell is oval, provisioned with the pollen load, and egg laying probably started in the $1^{\text {st }}$ to $2^{\text {nd }}$ weeks of June. Inside the cell, one egg was laid on top of the pollen ball, and the cell entrance was closed with a soil plug. In the same nest burrow, at a different depth, the second cell was made at the new end of the burrow proximal to the first cell. The soil that is shaved off from the second cell may be used for the plug. On average, 5.04 cells were prepared for each burrow. The last cell is without a pollen ball, or is either un-worked or unpolished and without an egg. The upper nest burrow is vertical and oblique to the horizontal line, with an orientation varying from 43 to $48^{\circ}$. The study showed that both sections can gradually shift with the bending or waving of the burrow. Generally, in the case of hard clay loam soil, bending and waving were not observed very much; however, in soft and moist soils, burrow waving was observed. The cells were placed obliquely along the main burrow. The mean diameter of the nest entrance recorded was $2.99 \mathrm{~mm}$; while the nest burrow is generally vertical, $2.83 \mathrm{~mm}$ in diameter, and $70.70 \mathrm{~cm}$ deep. The entrance is covered by a tumulus of 2.92 to $4.19 \mathrm{~cm}$ in diameter. Each burrow mostly contains 4 to 5 females and 1 or 2 males. These results are shown in Table 1. 
Table 1. Nesting features of $A$. patella at different soil depths from the entrance surface.

Significant differences at $* \mathrm{P} \leq 0.05$.

\begin{tabular}{|l|l|c|c|c|c|}
\hline \multirow{2}{*}{ Site No. } & Observation & \multicolumn{4}{|c|}{ Soil depths (cm) } \\
\hline & & 15.24 & 30.48 & 45.72 & 60.96 \\
\hline 1 & No. cells/nest & 5.75 & 4.43 & 4.01 & 2.30 \\
\hline 2 & Brood cell length & 12.34 & 11.75 & 9.54 & 7.71 \\
\hline 3 & Brood cell diameter & 3.76 & 3.42 & 2.13 & 2.11 \\
\hline 4 & Empty cell length & 6.17 & 5.43 & 5.21 & 4.00 \\
\hline 5 & Empty cell diameter & 2.19 & 1.75 & 1.32 & 1.01 \\
\hline 6 & Cell shape & oval, elongated & oval & oval & oval \\
\hline \multicolumn{2}{|l|}{ Tukey's Multiple Range test } & $* \mathrm{P}=0.021$ & $* \mathrm{P}=0.043$ & $* \mathrm{P}=0.049$ & $\mathrm{P}=0.661$ \\
\hline
\end{tabular}

Table 2. Nesting characteristics of $A$. patella in various landscapes (2013-2016).

Significant differences at $* \mathrm{P} \leq 0.05$.

\begin{tabular}{|c|c|c|c|c|c|c|}
\hline No. & Nest characteristic & 2013 & 2014 & 2015 & 2016 & Mean $\pm \mathrm{SE}$ \\
\hline 1 & Flight season & $\begin{array}{c}2^{\text {nd }}-3^{\text {rd }} \text { week } \\
\text { of May }\end{array}$ & $2^{\text {nd }}$ week May & $\begin{array}{l}12^{\text {th }} \text { May-26 th } \\
\text { May }\end{array}$ & $\begin{array}{l}15^{\text {th }} \text { May-25 } \\
\text { May }\end{array}$ & - \\
\hline 2 & Nest site observed & $\begin{array}{c}\text { Flat, level } \\
\text { ground, grassy } \\
\text { patches, } 7-13^{\text {th }} \\
\text { May }\end{array}$ & $\begin{array}{l}\text { Flat, no grass. } \\
12^{\text {th }} \text { of May }\end{array}$ & $\begin{array}{l}\text { Flat, hard, } \\
\text { no grass, } 1^{\text {st }} \\
\text { week June }\end{array}$ & $\begin{array}{l}\text { Flat, compact } \\
\text { soil, } 10^{\text {th }} \text { May }\end{array}$ & - \\
\hline 3 & Spatial distribution & Aggregates & Aggregation & $\begin{array}{l}\text { Aggregation/ } \\
\text { scattered }\end{array}$ & Aggregation & - \\
\hline 4 & Nest type & Linear & Linear & Linear & Linear & - \\
\hline 5 & Cell wall & $\begin{array}{l}2 \text { layered, } \\
\text { polished }\end{array}$ & $\begin{array}{l}\text { 1-2 layered, } \\
\text { fine }\end{array}$ & $\begin{array}{l}2 \text { layered, } \\
\text { Polished }\end{array}$ & Polished & - \\
\hline 6 & Shape of cell & Oval & - & oval & oval & - \\
\hline 7 & Orientation of cell & $\begin{array}{l}\text { Horizontal } \\
\text { to } 45-47^{\circ}\end{array}$ & $\begin{array}{l}\text { Horizontal, } \\
48^{\circ}\end{array}$ & - & $\begin{array}{l}\text { Horizontal, } \\
45^{\circ}\end{array}$ & - \\
\hline 8 & Nest density (nest $/ \mathrm{m}^{2}$ ) & 13.34 & 10.46 & 10.70 & 9.91 & $11.1 \pm 0.76$ \\
\hline 9 & Diameter of entrance (mm) & 2.22 & 3.20 & 2.87 & 3.67 & $2.99 \pm 0.13$ \\
\hline 10 & Diameter of burrow (mm) & 2.45 & 3.26 & 2.31 & 3.33 & $2.83 \pm 0.25$ \\
\hline 11 & Depth of nest bottom $(\mathrm{cm})$ & 65.54 & 75.11 & 78.32 & 63.98 & $70.7 \pm 2.91$ \\
\hline 12 & Depth of cell $(\mathrm{cm})$ & 34.32 & 45.54 & 40.65 & 49.59 & $42.5 \pm 1.86$ \\
\hline \multirow{2}{*}{13} & \multirow{2}{*}{$\begin{array}{l}\text { Cell size a) Diameter (mm) } \\
\text { b) Length (mm) }\end{array}$} & 3.02 & 3.43 & 3.11 & 3.01 & $3.14 \pm 0.21$ \\
\hline & & 10.33 & 9.78 & 10.10 & 9.80 & $10.0 \pm 0.46$ \\
\hline 14 & Number of brood cells/nest & 4.11 & 5.43 & 5.01 & 5.63 & $5.04 \pm 0.41$ \\
\hline 15 & Total empty cells/nest & 2.98 & 2.11 & 2.28 & 3.10 & $2.62 \pm 0.18$ \\
\hline 16 & Pollen ball weight (mg) & 12.21 & 13.09 & 8.91 & 10.90 & $11.2 \pm 0.93$ \\
\hline \multirow{2}{*}{17} & \multirow{2}{*}{$\begin{array}{l}\text { Egg a) Diameter (mm) } \\
\text { b) Length (mm) }\end{array}$} & 0.45 & 0.49 & 0.42 & 0.46 & $0.46 \pm 0.09$ \\
\hline & & 1.23 & 1.31 & 1.20 & 1.28 & $1.26 \pm 0.04$ \\
\hline \multicolumn{2}{|c|}{ Student's $t$-test } & $* \mathrm{P}<0.05$ & $* \mathrm{P}<0.05$ & $* \mathrm{P}<0.05$ & $* \mathrm{P}<0.05$ & \\
\hline
\end{tabular}


S. A. Dar et al.: Nesting biology of Andrena patella

Table 3. Courtship sequence of $A$. patella under field conditions. Significant differences at $* \mathrm{P} \leq 0.05$

\begin{tabular}{|l|c|c|c|c|c|}
\hline Male response & Attempts & $\begin{array}{c}\text { Duration } \\
\text { (seconds) }\end{array}$ & $\begin{array}{c}\text { Female } \\
\text { response }\end{array}$ & Attempts & $\begin{array}{c}\text { Duration } \\
\text { (seconds) }\end{array}$ \\
\hline $\begin{array}{l}\text { Male curled above } \\
\text { female }\end{array}$ & $3.33 \pm 0.54$ & $0.25 \pm 0.33$ & Still & $8.21 \pm 0.04$ \\
\hline $\begin{array}{l}\text { Forward movement, } \\
\text { holding by forelegs }\end{array}$ & $109 \pm 4.76$ & $10.3 \pm 0.98$ & $\begin{array}{c}\text { Foreleg } \\
\text { movement }\end{array}$ & $12.78 \pm 0.84$ & $3.33 \pm 0.34$ \\
\hline $\begin{array}{l}\text { Hind leg holding and } \\
\text { movement }\end{array}$ & $65.67 \pm 2.50$ & $9.11 \pm 0.01$ & Still & - & $5.50 \pm 0.59$ \\
\hline $\begin{array}{l}\text { Head holding } \\
\text { pronotum of female }\end{array}$ & $34.12 \pm 1.71$ & $4.23 \pm 0.31$ & Still & - & $6.32 \pm 0.51$ \\
\hline $\begin{array}{l}\text { Male movement } \\
\text { supported by hind } \\
\text { legs }\end{array}$ & $101.2 \pm 2.98$ & $5.54 \pm 0.69$ & $\begin{array}{c}\text { Hind leg } \\
\text { movement }\end{array}$ & $66.75 \pm 0.50$ & $13.23 \pm 0.34$ \\
\hline $\begin{array}{l}\text { Hind legs touch } \\
\text { genitalia }\end{array}$ & $87.80 \pm 4.29$ & $12.4 \pm 0.24$ & Still & - & $8.33 \pm 0.50$ \\
\hline $\begin{array}{l}\text { Male relaxes his } \\
\text { wings down and apart }\end{array}$ & $21.11 \pm 1.01$ & $3.01 \pm 0.71$ & Wing movement & $21.32 \pm 0.91$ & $3.32 \pm 0.04$ \\
\hline $\begin{array}{l}\text { Male makes aedeagus } \\
\text { movement }\end{array}$ & $3.36 \pm 0.35$ & $5.28 \pm 0.55$ & $\begin{array}{c}\text { Genitalia } \\
\text { movement }\end{array}$ & $4.33 \pm 0.62$ & $2.59 \pm 0.37$ \\
\hline $\begin{array}{l}\text { Males movesgenitalia } \\
\text { down }\end{array}$ & $4.57 \pm 0.39$ & $3.32 \pm 0.19$ & $\begin{array}{c}\text { Upward } \\
\text { movement }\end{array}$ & $4.53 \pm 0.60$ & $2.33 \pm 0.34$ \\
\hline Genitalia introminant & $3.46 \pm 0.30$ & $0.45 \pm 0.43$ & Inseminated & $0.56 \pm 0.94$ & $0.33 \pm 0.15$ \\
\hline
\end{tabular}

$0.03680 .0401-0.00190 .0498$; Kruskal Wallis test $* \mathrm{P}<0.05$

Table 4. Regression analysis (r) of the time interval (seconds) used in copulatory behavior of A. patella

\begin{tabular}{|l|l|r|r|r|c|}
\hline & df & \multicolumn{1}{|c|}{ SS } & MS & F & P \\
\hline Regression & 1 & 293.61 & 293.61 & 15.80 & 0.004 \\
\hline Residual & 8 & 148.61 & 18.57 & & \\
\hline Total & 9 & 442.22 & & & \\
\hline
\end{tabular}

Table 5. Probability of copulatory behavior events of $A$. patella under field conditions

\begin{tabular}{|l|c|c|c|c|c|c|}
\hline Source of variation & SS & df & MS & F & P & F crit. \\
\hline $\begin{array}{l}\text { Individual behavior, } \\
\text { all events }\end{array}$ & 14309.82 & 9 & 1589.98 & 2.16 & 0.032194 & 3.178893 \\
\hline $\begin{array}{l}\text { Male } \\
\text { +female behavioral events }\end{array}$ & 5228.40 & 1 & 5228.40 & 7.13 & 0.025607 & 5.117355 \\
\hline Error & 6598.88 & 9 & 733.20 & - & - & - \\
\hline Total & 26137.11 & 19 & & - & - & - \\
\hline
\end{tabular}



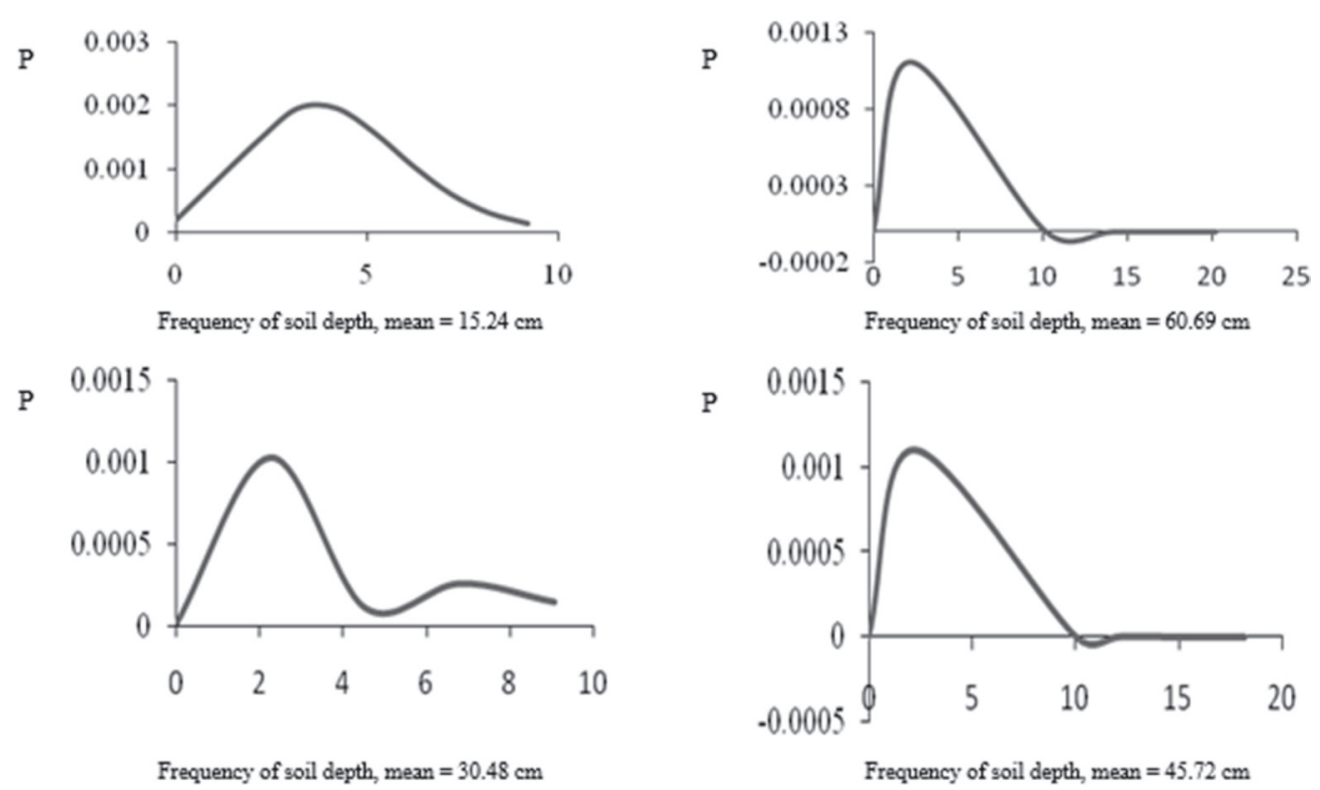

Fig. 1. Nest cell (empty and brood cells) occurrence at various soil depths. The Poisson distribution probability curve gives the probability of observing events at given depths. $\mathrm{P}$ - probability value; $1 \mathrm{inch}=2.54 \mathrm{~cm}$.

The mean depth of the cells is $38.03 \mathrm{~cm}$ from the main outer entrance. When conducting ANOVA, a non-significant difference in nesting features across all the experimental locations was observed. The cells observed varied in length, diameter and mean depth from the main burrow. We studied several nest aggregations across the sites, and 120 nests were excavated for exhaustive study. Therefore, after conducting the $\chi^{2}$ test the estimated value was 36.23 at 16 df (26.296), $\mathrm{P} \leq 0.05$. A statistical significance was found between various nest characteristics (Table 2), $\mathrm{P}<0.05$. The nest cell number and diameter and length varied with different depth categories, and total cell occurrence varied with the depth class of the soil horizon, as shown by Poison's probability distribution (Fig. 1). Further, nest cell parameters were statistically significant across different soil depths, except 60.69 $\mathrm{cm}, \mathrm{P}=0.661$.

Copulation and mating. On $15^{\text {th }}$ of May, a mating pair was observed at 2:30 pm, on a sunny warm day at a temperature of $17{ }^{\circ} \mathrm{C}$ and humidity of $78 \%$. The pair rested on a leaf for about 5 minutes, $3 \mathrm{~m}$ above the ground, less than $15 \mathrm{~m}$ from the nesting site. The male grasped the female with his legs, curled above the female and intermittently vibrated his wings. After mounting the female, the male curved his abdomen apex ventrally and inserted his genitalia into the female's reproductive orifice. The male exhibited forward movement several times, but the female showed no particular movements. In all of the mating attempts observed, the behavior was initiated by the male, and the male tried to copulate with the first female found near the nesting site, on flowers. During all the observed courtship attempts, the female's reaction involved a slight shaking of her body, and movement of her fore-legs, antennae, wings and genitalia. The various events in the mating behavior are presented in Table 3 .

On average, cell provisioning activity was observed in the $3^{\text {rd }}$ week of May when 22 bees were found to return to their nests with pollen. From the experimental location in Budgam, of the 4 females obtained after the nest excavation on the $4^{\text {th }}$ week of May 2015, 3 were already inseminated. The mating period of $A$. patella was the $3^{\text {rd }}$ week of May. Synchronously, several females were seen to fly to and from the nest site, and some crawled and alighted on the ground in search of a suitable nesting site. Several males were flying around on the nest site. All possessed nectar and pollen in crops and were inseminated. The mating behavioral elements were analyzed in terms of duration, and the estimated $\chi^{2}$ value was 5.99 at $5 \mathrm{df}(14.744)$, 
$\mathrm{p}<0.005$. For copulatory behavior, the regression analysis of the various movements is given in Table 4. Further, the data of frequency of copulation behavior did not follow a scholastic matrix, since the probability of male behavior was greater, and the females were still, the probability was $>1$. Following the Markovian behavior transition matrix, the probability of events was found to be 0 and 1 ( $1^{\text {st }}$ generation matrix), and the probability of a $2^{\text {nd }}$ generation event was $>25 \%$ (Table 5). Behavioral copulatory events showed that males are more proactive and aggressive than females.

\section{Discussion}

The current study showed that the nests of A. patella were scattered over the flat areas, however, the majority of them were aggregated. The differences in the occurrences of nesting aggregations were probably influenced strongly by landscape composition, which in turn has a strong impact on the female bee's ability to locate and obtain quality nesting and provisioning resources (CANE and TEPEDINO, 2016; RENAULD et al., 2016; SOH et al., 2016). Under the temperate conditions of the Kashmir valley, the emergence of A. patella started at the end of March and lasted until the first week of April. Bees rely on floral and nesting resources, and once these resources become scare, bees are more likely to use resources farther from their nesting sites, which may increase the nest's vulnerability to cleptoparasites (GOODELL, 2003; KRUNIĆ et al., 2005; SEIDELMANN et al., 2006; TLAK GAJGER et al., 2014; TLAK GAJGER et al., 2015), so resulting in a reduction in their spatial distribution across sites. In the current study, the nests formed dense aggregations within a range of about $12.50 \mathrm{~km}$ in length across all locations, generally between paths and adjoining grassy ground with compact clay loam soil. The maximum nest aggregations observed were in southern area of the valley, which is in agreement with ELSE et al. (2016) where A clarkella nests were found on the southern sides, in marshy, dry and barren land. The nesting sites were dominant on paths made of hard clay loam soil, in the center of paths, with a mean nest density of 11.10 nests/ $\mathrm{m}^{2}$, which is in accordance with observations of ELSE et al. (2016). We observed a higher abundance of nest aggregations in experimental locations in Budgam, but overall the differences were non-significant across all sites over the four years of the study. However, the researchers found a highly heterogeneous pattern of bee profusion and spatial distribution across the landscapes $(\mathrm{KOH}$ et al., 2015).

We observed an increase in bee activity with a rise in temperature, and the critical temperatures for flight of $A$. patella were 15 to $21{ }^{\circ} \mathrm{C}$. However, the critical temperature for the flight of most Andrena species is 12 to $14{ }^{\circ} \mathrm{C}$. The males were observed to fly around the nest until the $1^{\text {st }}$ week of June $\left(6^{\text {th }}\right.$ June). On average the female life span is for 49 to 53 days while the males lived for nearly 34 days. This is in close conformity with STRAKA et al. (2014) where the length of life span from the first to last appearance was 38 days for Andrena vaga and 41 days for Anthophora plumpes, respectively. ROBBIRT et al. (2014) investigated how warming air by $2{ }^{\circ} \mathrm{C}$ increased the probability of male and female flight in Andrena nigroaenea, however, OLIVEIRA et al. (2016) and DRUMMOND (2016) reported that a change in temperature had a nonsignificant effect on bee flight patterns. According to MICHENER and RETTENMEYER (1956), Andrena erythronii started short flights near their nests, and also suggested the importance of surface temperature, soil temperature, wind and sunshine hours for their flight activities. The orientation of the larvae changes continuously until feeding was completed, and this style of larval feeding and the movements and orientation of the larvae are also confirmed by the results of MILICZKY and OSGOOD (1995). The orientation of larvae changed gradually with their development. The change in their morphology was more rapid when an abundant provision mass was available and consumed. With the increase in larval size, the movement of the larvae increased rapidly from forward and downward at the front of the mass, with sideways movements of the head, and the larvae wrapped tightly around the remains of the provisions in the cell. Before larvae defecate, they rest on their dorsal surface with their head towards the mouth of the cell and tail towards the rear. 
Once a larva defecates, the feces are placed against the rear of the cell. The feces deposits varied in thickness and color.

Up to nearly $10.16 \mathrm{~cm}$ in depth, the nest diameter does not vary much outside or inside, but later it becomes narrower. The external diameter of the entrance is more or less similar to the main burrow (internal) to a certain depth, but not as conspicuous as in Lasioglossum marginatum (DAR, 2017). SCOTT et al. (2016) observed that the nest depth of Andrena crataegi varied from 30 to $41 \mathrm{~cm}$. Our study showed that at an average depth of $22.86 \mathrm{~cm}$, each cell directly opened onto the main burrow through proximal tunnels, either alternately or unilaterally.

During the current study, the foraging activity of the species started in May, and the males started patrolling the females during April. The males of $A$. patella have strong legs, they jump onto the females and grasp her abdomen with their legs, keeping their head in an erect, forward direction, the same as the activated female. According to SCHIESTL and AYASSE (2000), the cuticles of the young females elicits copulatory activity in the males, with the release of all-trans-farnesyl hexanonate and alltrans-farnesol, a compound abundant in the cuticles of unmated females of $A$. nigroaenea which attracts the males. The males have developed specialized antennae to recognize minimal amounts of female sex pheromone (ROITBERG and ISMAN, 1992). The female sex pheromones are used to attract males, and to elicit territorial and courtship behavior in males (KRIEGER et al., 2006). In Osmia rufa, unmated females attract males using a sex pheromone that elicits intensive courtship behavior, during which males try to mount each other in their attempts to mate (CONRAD et al., 2017). During the male's attempts to introduce the edeagus into the female's genital cavity, the female responds by touching the leaf with her ventral body surface. Overall, the females remain quite still during courtship and do not fly away.

\section{Conclusion}

A. patella bees nest in soil and feed on the flowers of fruit crops from early spring to summer. Bees rely on floral and nesting resources. The landscape has a strong influence on the differences in composition and the occurrence of nesting aggregations. The majority of the observed nests were aggregated, and a few of them were scattered over flat areas. During the four years of the study, foraging behavior, mating, nest and cell structure, the formation of the provision mass, egg placement, and larval feeding were observed as the main features of nesting biology. The values of all the observed features were similar in all experimental locations.

From the point of view of pollination, conservation of the habitat and habitat availability are important. Therefore, special emphasis in future studies should be placed on the habitat requirements, biology, second generation, seasonal activity and alternate foraging plants for this species. Moreover, the brood parasites and other threats that are harmful to this species need to be explored, as well as the effect of soil pollution on egg laying and overwintering.

\section{References}

ALCOCK, J. (1975): Territorial behavior by males of Philanthus multimaculatus (Hymenoptera: Sphecidae). Anim. Behav. 234, 889-895.

DOI: 10.1016/0003-3472(75)90113-X

BAKER, D. B. (1995): A new Malayan Andrena (Hymenoptera: Apoidea). Dtsch. Entomol. Z. 42, 1, 67-69.

BArbosa, F. M., R. M. O. Alves, B. A. SOUZA, C. A. L. CARVALHO (2013): Nest architecture of the stingless bee Geotrigona subterranea (Friese, 1901) (Hymenoptera: Apidae: Meliponini), Biota Neotrop. 13, 1, 1-10.

BISCHOFF, I., F. KERSTEIN, D. BRECKNER (2003): Foraging strategy and pollen preferences of Andrena vaga (Panzer) and Colletes cunicularius L. (Hymenoptera). J. Hymenopt. Res. 12, 220-237.

BOHART, G. E, N. N. YOUSSEF (1976): The biology and behaviour of Evylaeus galpinsiae Cockerell (Hymenoptera: Halictidae). Wasmann J. Biol. 34, 185-234.

CANE, J. H, V. J. TEPEDINO (2016): Gauging the effect of honey bee pollen collection on native bee communities. Conserv. Lett. 10, 2, 205-210.

DOI: $10.1111 /$ conl.12263

CONRAD, T., C. STOKER, M. AYASSE (2017): The effect of temperature on male mating signals and female choice in the red mason bee, Osmia bicornis L. Ecol. Evol. 7, 21, 8966-8975.

DOI: $10.1002 /$ ece 3.3331 
DANFORTH, B. N. (1991): Female foraging and intra nest behavior of a communal bee, Perdita portalis (Hymenoptera: Andrenidae). Ann. Entomol. Soc. Am. 84, 537-548.

DAR, S. A. (2017): Species diversity, relative abundance and nesting behaviour of insect pollinators of stone fruits (peach, plum and cherry) in Kashmir valley. PhD Thesis. Department of Entomology, SKUAST-K, Srinagar, India.

DAR, S.A., H. M. SAJAD, G. M.MIR(2017): Nesting behaviour of Andrena cineraria Linnaeus (Hymenoptera: Andrenidae) in temperate areas of India. National Conference on Climate Change and Agricultural Production-Adapting Crops to Increased Climate Variability and Uncertainty. $6^{\text {th }} 7^{\text {th }}$ April 2017, Bihar Agricultural University, Sabour, Bhagalpur, pp. 631-632.

DAR, S. A., A. R. WANI, M. A. SOFI (2018): Diversity and abundance of insect pollinators of sweet cherry Prunus avium in Kashmir valley. Indian J. Entomol. 80, 3, 725736.

DOI: $10.5958 / 0974-8172.2018 .00231 .6$

DEMERE, T., B. D. H. HOLLINGSWORTH, P. UNITT (2002): Nest and nest building animals. San Diego Natural History Museum. Field Notes, pp. 1-15.

DRUMMOND, F. A. (2016): Behavior of bees associated with the wild blueberry agro-ecosystem in the USA. Int. J. Entomol. Nematol. 2, 27-41.

ELSE, G. R., B. BOLTON, G. R. BROAD (2016): Checklist of British and Irish Hymenoptera - aculeate (Apoidea, Chrysi DOIdea and Vespoidea). Biodivers. Data J. 4, e8050.

DOI: 10.3897/BDJ.4.e8050

GESLIN, B., V. L. FÉON, Y. FOLSCHWEILLER (2016): The proportion of impervious surfaces at the landscape scale structures wild bee assemblages in a densely populated region. Ecol. Evol. 6, 18, 6599-6615.

DOI: $10.1002 /$ ece 3.2374

GIOVANETTI, M., E. LASSO (2005): Body size, loading capacity and rate of reproduction in the communal bee Andrena agilissima (Hymenoptera: Andrenidae). Apidologie 36, 439-447. DOI: 10.1051/apido:2005028

GOODELL, K. (2003): Food availability affects Osmia pumila (Hymenoptera: Megachilidae) foraging, reproduction and brood parasitism. Oecologia 134, 518-427.

DOI: $10.1007 / \mathrm{s} 00442-002-1159-2$

KATERINA, C. (2013): Nesting behaviour and population genetics of solitary bees (Hymenoptera: Anthophila). PhD Thesis. Charles University Faculty of Sciences, Prague, Czech Republic.

KEMP, W. P., J. BOSCH (2000): Development and Emergence of the Alfalfa Pollinator Megachile rotundata (Hymenoptera: Megachilidae). Ann. Entomol. Soc. Am. 93, 4, 904-911.

DOI:10.1603/0013-8746(2000)093[0904:DAEOTA]2.0.CO;2
KOH, I., E. LONSDORF, V. WILLIAMS, N. M. BRITTAINS, C. ISAACS, R. J. GIBBS, T. H. RICKETTS (2015): Modeling the status, trends, and impacts of wild bee abundance in the United States. PNAS 113, 1, 140-145.

DOI: 10.1073/pnas.1517685113

KRIEGER, G. M., M. DUCHATEAU, A. V. DOORN, F. IBARRA, W. FRANCKE, M. AYASSE (2006): Identification of queen sex pheromone components of the bumblebee Bombus terrestris. J. Chem. Ecol. 32, 453-471. DOI: $10.1007 / \mathrm{s} 10886-005-9013-8$

KRUNIĆ, M., L. STANISAVLJEVIĆ, M. PINZAUTI, A. FELICIOLI (2005): The accompanying fauna of Osmia cornuta and Osmia rufa and effective measures of protection. Bull. Insectol. 58, 2, 141-152.

KUMAR, M. L., D. DEY (2018): Systematic studies of subgenus Melandrena (Andrena). J. Entomol. Zool. Stud. 6, 4, 1299-1304.

MAYR, E., P. D. ASHLOCK (1991): Principles of systematic zoology. McGraw-Hill Inc., New York.

MICHENER, C. D., C. W. RELTENMEYER (1956): The Ethology of Andrena erythronii with comparative data on the species of Andrena. Uni. Kansas Sci. Bull. 37, 645-684.

MILICZKY, E. (2016): Observations on the nesting biology of three species of Panurgine bees (Hymenoptera: Andrenidae). J. Kansas Entomol. Soc. 64, 1, 80-87.

MILICZKY, E. R., A. E. OSGOOD (1995): Bionomics of Andrena (Melandrena) vicina Smith in Maine and Washington, with new parasite records for Andrena (M.) regularis Malloch and a review of Melandrena biology. J. Kansas Entomol. Soc. 68, 51-66.

MILIUS, S. (2007): Most bees live alone: No hives, no honey, but maybe help for crops. Sci News 171, 11-13. DOI:10.1002/scin.2007.5591710110.

MOUNTCASTlE, A. M., S. RAVI, S. A. COMBES (2015): Nectar vs. pollen loading affects the tradeoff between flight stability and maneuverability in bumblebees. PNAS 112, 33, 10527-10532.

DOI:10.1073/pnas.1506126112

ORR, M. C., T. GRISWOLD, J. P. PITTS, F. D. PARKER (2016): A new bee species that excavates sandstone nests. Curr. Bio. 26, 17, R792.

DOI: $10.1016 /$ j.cub.2016.08.001

OLIVEIRA, M. O., B. M. FREITAS, J. SCHEPER, D. KLEIJN (2016): Size and sex-dependent shrinkage of dutch bees during. one-and-a-half centuries of land-use change. PLoS ONE 11, 2, e0148983.

DOI: 10.1371/journal.pone.0148983

PARKER, J. F., P. HOPLEY, B. F. KUHN (2016): Fossil Carder Bee's nest from the Hominin locality of Taung, South Africa. PLoS ONE 11, 9, e0161198.

DOI: 10.1371/journal.pone.0161198 
PAXTON, R. J., N. WEISSSCHUH, W. ENGELS, K. HARTFELDER, J. JAVIER, G. QUEZADA-EUAN (1999): Not only single mating in stingless bees. Naturwissenschaften 86, 143-146.

PAXTON, R. J., M. GIOVANETTI, F. S. ANDRIETTI, E. SCARNONI, B. SCANNI (1999a): Mating in a primitively social bee, Andrena agilissima (Hymenoptera Andrenidae). Ethol. Ecol. Evol. 11, 371-383.

RENAULD, M., A. HUTCHINSON, G. LOEB, K. POVEDA, H. CONNELLY (2016): Landscape Simplification Constrains Adult Size in a Native Ground-Nesting Bee. PLoS ONE, 11, 3, e0150946.

DOI: $10.5061 /$ dryad.kr577

ROBBIRT, K. M., D. L. ROBERTS, M. J. HUTCHINGS, J. DAVY (2014): Potential Disruption of Pollination in a Sexually. Deceptive Orchid by Climatic Change. Curr. Biol. 24, 3, 2845-2849.

DOI: 10.1016/J.CUB.2014.10.033

ROCHE, F. L., J. F. GENISE, C. CASTILlO, J. D. NUFEZ (2014): Fossil bee cells from the Canary Islands. Ichnotaxonomy, palaeobiology and palaeoenvironments of Palmiraichnus castellanosi. Palaeog. Palaeoclim. Palaeoec. 409, 249-264.

DOI: 10.1016/j.palaeo.2014.05.012

ROITBERG, B. D., M. B. ISMAN (1992): Insect chemical ecology. An evolutionary approach. Chapman and Hall, New York.

ROUBIK, D. W. (2006): Stingless bee nesting biology. Apidologie 37, 124-143.

DOI: 10.1051/apido:2006026

ROZEN, J. G. (1993): Phylogenetic relationships of Euherbstia with other short-tongued bees (Hymenoptera: Apoidea). Am. Mus. Novit. 360, 1-17.

ROZEN, J. G., H. ÖZBEK, J. S. ASCHER, M. G. RIGHTMYER (2009): Biology of the bee Hoplitis (Hoplitis) monstrabilis Tkalcu and descriptions of its egg and larva (Megachilidae: Megachilinae: Osmiini). Am. Mus. Novit. 3645, 1-12.

DOI: $10.1206 / 646.1$

SARZETTI L. C., J. F. GENISE, M. V. SÁNCHEZ (2014): Nest architecture of Oxaea austera (Andrenidae: Oxaeinae) and its significance for the interpretation of Uruguayan fossil bee cells. JHR 39, 59-70.

DOI: $10.3897 /$ JHR.39.8201

SCHIESTL, F. P., M. AYASSE (2000): Post mating odour in females of solitary bees Andrena nigroaeanea (Apoidae: Andrenidane) inhibits male mating behaviour, behavioural ecological social biology. Behav. Ecol. Sociobiol. 48, 303307.

DOI: $10.1007 / \mathrm{s} 002650000241$

SCOTT, Z., H. S. GINSBERG, S. R. ALM (2016): Native bee diversity and pollen foraging specificity in cultivated highbush blueberry (Ericaceae: Vaccinium corymbosum) in Rhode Island. Environ Entomol. 45, 6, 1432-1438.

DOI: org/10.1093/ee/nvw094

SEIDELMANN, K. (2006): Open-cell parasitism shapes maternal investment patterns in the red Mason bee Osmia rufa. Behav Ecol. 17, 839-848.

DOI: 10.1093/beheco/arl017

SOH, M. C. K., N. S. SODHI, R. K. H. SEOH, B- W. BROOK (2020): Nest site selection of the House Crow (Corvus splendens), an urban invasive bird in Singapore and implications for its management. Landsc. Urban Plan. 59, 217-226.

DOI: 10.1016/S0169-2046(02)00047-6

STRAKA, J., M. K. CERNA, L. MACHÁČKOVÁ, M. ZEMENOVÁ, P. KEIL (2014): Life span in the wild: the role of activity and climate in natural populations of bees. Funct Ecol. 28, 5, 1235-1244.

DOI: $10.1111 / 1365-2435.12261$

TLAK GAJGER, I., M. JURKOVIĆ, A. KOŠČEVIĆ, I. LAKLIJA, M. ŠEVAR (2014): Prevalence of Cacoxenus indagator larvas in Osmia spp. artificial nests settled in Croatia. Book of abstracts ApiEcoFlora and Biodiversity International Symposium. 6- $7^{\text {th }}$ November 2014, Roma, Italy, pp. 73.

TLAK GAJGER, I., I. LAKLIJA, A. KOŠČEVIĆ, M. JURKOVIĆ, M. ŠEVAR (2015): Section analysis of solitary bees (Osmia spp.) artificial nests. Book of abstracts $6^{\text {th }}$ International Congress Veterinary science and profession, 1-2 ${ }^{\text {nd }}$ October 2015, Zagreb, 104-105.

Received: 18 June 2020

Accepted: 15 October 2020

\section{DAR, S. A., M. YAQOOB, I. TLAK GAJGER: Ponašanje pri gniježđenju i parenju pčele Andrena patella (Hymenoptera: Andrenidae). Vet. arhiv 91, 207-219, 2021.}

\section{SAŽETAK}

Istraživanje gniježđenja i povezanih obrazaca ponašanja pčele Andrena patella provedeno je na 27 lokacija različitih krajobraznih kategorija, od 2013. do 2016. godine. Odabrana područja istraživanja općenito su bila ravna i vlažna. Uočeno je 15 velikih agregacija gnijezda, a iskopano je 120 gnijezda. U vrsta koje su bile ugniježđene na 
glinenom zemljištu mužjaci su se razvili prije ženki, a parenje se zbilo na cvijeću za vrijeme sezone paše, treći tjedan u svibnju. Različiti pokazatelji gnijezda i stanica pokazali su nisku varijabilnost u različitim godinama i na različitim lokacijama, no dužina stanica saća, njihov promjer i broj statistički su se znakovito razlikovali čak i na istom mjestu. Gnijezda su bila multistanična, kosa do vodoravna, a oblik stanica ovalan. Pokušaj parenja i kopulacijsko ponašanje uključili su različite faze koje su završene u nekoliko sekunda. Mužjaci su se prvi pojavili na cvijeću, blizu mjesta za gniježđenje, i živjeli su kraće od ženki. Ženke su počele s pašom drugi i treći tjedan svibnja, a jajašca su položile prvi tjedan u lipnju. Opisani su oblici odraslih jedinki, polaganje jaja, opskrba stanica i hranjenje ličinki

Ključne riječi: fenologija pčele Andrena patella; ponašanje; razvojni stadiji; proizvodnja peludi i nektara 
